International Journal of Instruction e-ISSN: 1308-1470 • www.e-iji.net

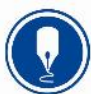

October $2019 \bullet$ Vol.12, No.4

p-ISSN: 1694-609X

pp. 625-638

Received: 10/02/2019

Revision: 04/07/2019

Accepted: 09/07/2019

OnlineFirst:10/09/2019

\title{
Differentiated Instruction in Relation to Pupils' Learning Style
}

\author{
Marjon C. Malacapay \\ Central Philippines State University, Philippines, mcmalacapay@gmail.com
}

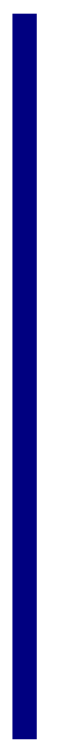

\begin{abstract}
Differentiating of instruction is salient as learners absorb information at their own styles. Differentiating of instruction is salient as learners absorb information at their own styles. Thus, determining their preferred mode of instruction as to their learning style is important. In attaining this, the researcher first determined the respondents' $(\mathrm{n}=30)$ demographic profile, academic achievement, and learning styles by distributing a survey questionnaire and further sought significant association among them. Being an action research by design, the researcher used both descriptive and inferential statistics such as frequency and percentage distribution, mean and Chi-square to treat the data. Findings show that the respondents are partly Indigenous Peoples, mostly male, whose favorite hobby is drawing, and radio is the primary source of information. Among them, auditory learners with very satisfactory academic achievement dominated. Furthermore, findings revealed that there was no significant difference between the demographic profile and learning styles. Thus, no significant relationship was also flaunted between learning styles and academic achievement. Lastly, it shows that both visual and auditory learners learned best when the teacher used audio-visual presentations while kinesthetic learners learned best when applied to real objects. This implies that learning styles are independent, not limited, nor not driven by a demographic profile and are not influenced by academic achievement.
\end{abstract}

Keywords: basic education, differentiated instruction, teaching pedagogy, Philippines, instruction

\section{INTRODUCTION}

\section{Background of the Study}

Pupils of this generation do not just want to sit the entire day listening to their teachers doing most of the talks in class. In fact, in an article written by Bryner (2007) in Live Science, pointed out and highlighted that two out of three students get bored in their class; 30 percent of them said it was due to lack of interaction while 70 percent was due to non-interest-bearing report materials being taught. That is why, it is a must for teachers to modify the content, process, or products by differentiating their instruction 
(Tomlinson et. Al., 2003). But prior to that, they must profile what kind of learning styles their learners have (Teach.com, 2018).

Identifying the learning styles of students in school is considered as a teacher's responsibility (Shenoy \& Shenoy, 2013). Profiling them enables the teacher to gain a better outlook on how learners obtain information. Also, being knowledgeable about the learning styles at educational institutes helps solve learning problems among students and allows students to become better learners (Sarabi, Asiabar, Jafari, Sadeghifar, Tofighi, Zaboli, Peyman \& Shams, 2014).

Even if identifying the learning style is a complicated issue, several models have been proposed by different authors in order to categorize each style (García, Amandi, Schiaffino, and Campo, 2007). One of those models was the famous VAK (Visual, Auditory, and Kinesthetic) Model of Neil Flemming in 2001. Other models identified by The Peak Performance Center (n.d.), an organization that provides resources to organization to achieve performance excellence, are the 4MAT Learning Style Model, Gregoric Mind Style Model, Kob Learning Style Model, Honey Mumford Learning Style, Felder-Silverman Learning Style, Hermann's Brain Dominance (HBDI), Leftbrain and Right-brain Preference, and Myers-Briggs Type Indicator (MBTI). All these models have various assumptions and focus on different aspects (García, et al., 2007). Therefore, profiling of learning styles benefited teachers by gaining a clearer perspective on the proper implementation of instruction and teaching techniques in class (Teach.com, 2018; Hylton, 2017).

In order to increase motivation and improve students' performance as well as to meet their preferred learning styles, it is important to update and fit teaching methods and evaluate their efficacy (Norman, 2009). Such suggested teaching method and instructions are the use of manipulative, visual aids, charts, audiotapes, and explicit expectations (Lawrence-Brown, 2014). Since learners acquire and process information at their own style such as seeing, hearing, reflection and action, thought analysis and imagination, differentiating of instruction is important (Jacques \& Salmon, 2006).

Differentiated instruction represents the new classroom teaching model as the schools' attempt to meet the needs of a diverse student community. Among the prominent models of differentiation is Tomlinson's (2003) model, which proposes that teachers modify the content, process, or products to meet the varied needs of students. Rock, Gregg, Ellis, and Gable (2008) as cited by Landrum and McDuffie (2010) explained the theoretical framework of differentiated instruction, based on Tomlinson's work, through four guiding principles and seven essential beliefs. The four guiding philosophies include (a) a focus on vital ideas and skills in each subject area, (b) openness to individual student differences, (c) incorporation of assessment and instruction, and (d) ongoing adjustment of content, process, and products to meet the individual students' levels of earlier knowledge, critical thinking, and expression styles (Rock, et. al., 2008; p. 33). Furthermore, he described seven essential beliefs about differentiated instruction, again based on Tomlinson's work, which includes (a) experiences in life and readiness to learn to differ is much among same-aged students; (b) these difference have a much effect on their learning; (c) students' learning is heightened when teachers challenge them beyond 
their independent level; (d) learning is more effective when related to real-life situations; (e) student learning is enhanced by authentic learning opportunities; (f) student learning is increased when they are respected and valued by their teachers, school, and community; and (g) the utmost goal of education is to recognize and promote the abilities of each student. Based on these expectations, teachers can differentiate instruction by adjusting the content, process, and products based on students' readiness, interest, and learning profiles (Tomlinson, 1999; Rock et al., 2008).

In fact, differentiating of instruction was already proven to consistently yield positive results (McQuarrie, McRae, \& Stack-Cutler, 2008). It ensures all types of learners, with varied learning styles, challenged. Furthermore, it provides struggling readers to become self-sufficient, confident, and competent individuals, and increases students' academic performance than those exposed in a traditional lecture method (Aranda \& Zamora, 2016; Leonardo, Nivera, \& Reyes, 2015; Ferrier, 2007; Tieso, 2005). It is also important because students process and acquire information in various ways such as seeing and hearing, as well as reflection and action, thought, analysis and imagination (Jacques and Salmon, 2006). For the arguments presented, differentiating the instruction can be better executed by identifying first the preferred learning styles of students (Othman \& Amiruddin, 2010).

Despite gaining ground in many educational circles, practicing of Differentiated Instruction in class has become a challenge and had made the role of teachers complex (Tomlinson \& Moon, 2014; Dixon, Yssel, McConnell, \& Hardin, 2014). One of the challenges is teaching methods variation. Kauffman, Mock, Tankersley, and Landrum (2008) discussed the confusion of teachers that differentiated instruction means a oneon-one instructional arrangement. Some teachers even continuously apply traditional teaching instructions such as lecture or demonstration, discovery learning, principle application, memorization, and comprehension as well. The danger is, when learning styles mismatched with teaching styles, the students may become bored, inattentive, do poorly on tests, get discouraged, and lack interest in the class. (Singh, 2015). Thus, this study aimed to bridge the gap by identifying the learners' preferred instruction in accordance with their learning style to provide a conducive learning experience.

\section{Statement of the Problem}

The main purpose of this study was to determine the preferred learning instruction of the learners. Specifically, it aimed to answer these questions:

1. What is the learner's demographic profile in terms of a.) sex; b.) ethnicity; c.) access to learning resource; and d.) hobby?

2. What is the learner's learning style when taken as a whole and when grouped according to a.) visual; b.) auditory; and d.) kinesthetic?

3. What is the learner's academic achievement when taken as a whole and when grouped according to a.) visual; b.) auditory; and c.) kinesthetic?

4. Is there a significant difference between the learners' demographic profile and learning styles?

5. Is there a significant relationship between learners' learning styles and academic achievement? 
6. What is the learner's preferred learning instruction when grouped according to a.) visual; b.) auditory; and c.) kinesthetic?

\section{Null Hypotheses}

1. There is no significant difference between learners' demographic profile and learning styles.

2. There is no significant relationship between learners' learning styles towards their academic achievement.

\section{Scope and Limitation}

The scope of work presented has several limitations. First, the study focused and is limited only in three learning styles such as visual, auditory, and kinesthetic as enumerated by Flemming (2001) for the researcher's convenience in preparing tasks and materials. It was also limited and administered to grade five pupils $(\mathrm{n}=30)$ only. This study is further limited to the second grading period objectives and topics of Values Education, Math, Social Studies, English, Math, Filipino, Music, Arts, Physical Education and Health (MAPEH), and Technology and Livelihood Education (TLE) subjects reflected in the curriculum guide of the Department of Education. The activities used by the researcher in four sessions per subject were selected by himself based on his readings on the internet and were further validated (content and criterion) by three jurors.

\section{METHOD}

This research study used an action research design since the study is quantitative. Applying this design to a current situation helps the researcher to later develop a plan to improve it (VanBaren, 2019). In this study, identifying an accurate and research-based teaching instruction grounded on learners' preferences became the researcher's major goal.

\section{Participants}

All the 30 grade five learners in his advisory class in one of the far-flung schools of Kabankalan City, Negros Occidental, Philippines had been purposely selected as respondents for his convenience. The use of the entire population as a sampling method was a purposive choice, otherwise known as complete enumeration. Complete enumeration enables the researcher to look at the population with a particular set of characteristics (Hale, 2011).

\section{Instrument}

In order to generate information, the researcher used a two-part self-translated survey questionnaire patterned from a standardized survey questionnaire in What's Your Learning Style (2009). The respondents' convenience had been the primary reason for translating the instrument's original texts into the learners' own mother-tongue (Hiligaynon). Moreover, the researcher did formative assessment tools in order to assess the learners' comprehension on a specific lesson, a self-made tally sheet to record their 
formative scores in each session, and a structured interview questionnaire to corroborate the findings of quantitative research.

\section{Validity and Reliability of Instrument}

All tools including the research instrument, the lessons' content used in each instructional material, and the formative assessment tools underwent two phases of validity tests (content and criterion). First, the researcher presented the content of the lesson found in each instructional material and the formative assessment tools to be used during the four sessions to three subject matter experts for content validation, thorough review, and analysis. After consolidating the comments and revision, a content refinement of the instrument followed. Then, the research instrument underwent criterion validity and reliability testing. Using the criteria set forth by Carter V. Good and Douglas E. Scates in evaluating how valid an instrument is, the three jurors rated the questionnaire with a consolidated mean of 4.74 which was interpreted as valid. Next, the researcher conducted a reliability testing of the questionnaire on randomly selected grade six pupils $(n=15)$ employing the test-retest method. Then, the data gathered was analyzed using the Cronbach's Alpha in SPSS Statistics which caused a Cronbach's Alpha of $0.99(a \geq 0.9)$ interpreted as excellent. Furthermore, the researcher used the learners' Form 137 or the Progress Report Card as the basis of pupils' academic achievement.

\section{Data Gathering}

The data gathering took place after a series of instrument validation. The researcher sought written and verbal permission from the School Head and the parents, stating the aims of the study and for parental consent. A face-to-face orientation of the researcher among his participants, highlighting their voluntary involvement, took place. Fortunately, everyone participated. Profiling of learners became the starting point of the data gathering procedure. After profiling, the researcher grouped the learners according to their learning styles and integrated differentiated instruction. The researcher utilized the different instructional materials and teaching strategies in each session with the students and conducted formative tests right after. After completing the four sessions, responses and perceptions from six pupils (two from each group) were gathered using a random, one-on-one interview through the use of structured interview questions. The researcher asked only two questions such as "Ano sa mga hilikuton ang imo pinaka na luyagan? [What activities did you like the most from all the activities that we had made? kag ngaa [Why]?" in order to justify the numerical results. This became the basis for making a research conclusion about the learners' preferred instruction. The data gathering took almost two months (middle of September to the first week of November) because of the time needed in preparing such instructional materials. After gathering, consolidating, and encoding the results, it underwent data analysis using the SPSS application.

\section{Data Treatment}

The researcher used both descriptive and inferential statistics for data treatment such as frequency counts to find the respondents' profile and learning style, mean for academic 
achievement, percentages for the effectiveness of each instruction, and Pearson-r with a .05 threshold to decide the relationship among variables.

\section{FINDINGS AND DISCUSSION}

Presented herewith are the results of data treatment and its corresponding analysis.

Table 1

The Demographic Profile Distribution of Grade 5 Pupils

\begin{tabular}{lll}
\hline Demographic Profile & Frequency & Percent \\
\hline Sex & 20 & \\
Male & 10 & 67 \\
Female & 30 & 33 \\
Total & & 100 \\
Ethnicity & 12 & \\
Indigenous Peoples (IP's) & 18 & 40 \\
Non-IP's & 30 & 60 \\
Total & & 100 \\
Access to Learning & 11 & \\
Books & 6 & 37 \\
Cellphone & 1 & 20 \\
Television & 12 & 3 \\
Radio & 0 & 40 \\
Abacus/Counters & 0 & 0 \\
VCD/DVD & 30 & 0 \\
Total & & 100 \\
Hobby & 1 & \\
Reading & 5 & 3 \\
Singing & 13 & 17 \\
Drawing & 8 & 43 \\
Talking & 2 & 27 \\
Listening to Music & 0 & 7 \\
Playing Instrument & 1 & 0 \\
Playing with Friends & 0 & 3 \\
Doing House Chores & 0 & 0 \\
Hiking & 30 & 0 \\
\hline Total & & 100 \\
\hline & & \\
Tol & &
\end{tabular}

The demographic profile distribution in table 1 shows that among 30 respondents, male learners dominated at 67 percent (20), a multi-cultural class having 60 percent (18) nonIndigenous Peoples, 40 percent (12) have radios at home which serves as their access to learn, and 43 percent (13) of them loves to draw. 
Table 2

Frequency Distribution Table of the Learners' Learning Style

\begin{tabular}{lll}
\hline Learning Styles & Frequency & Percent \\
\hline Visual & 9 & 30 \\
Auditory & 14 & 47 \\
Kinesthetics & 7 & 23 \\
\hline Total & 30 & 100 \\
\hline
\end{tabular}

The frequency of the learner's learning style distribution in Table 2 reveals that out of 30 respondents, auditory learners dominated with 47 percent (14) followed by visual and kinesthetic. It implies that the majority of the learners, when classified in to three groups, learn best through listening.

Table 3

The Learners' Academic Achievement

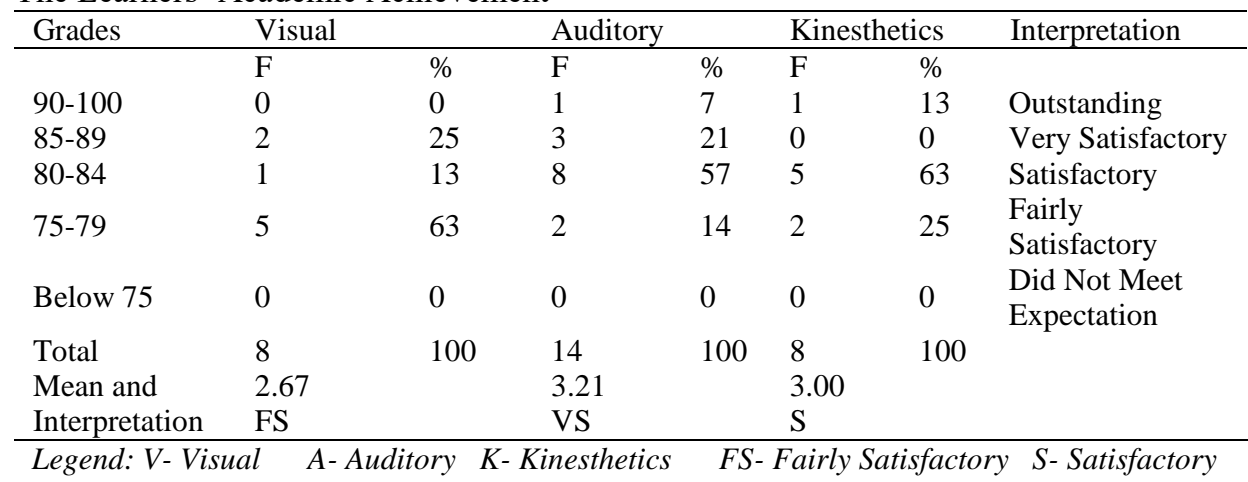

The learners' academic achievement distribution in Table 3 exhibits the mode and mean scores of grades five pupils' academic achievement. When respondents are grouped according to learning styles, visual learners performed fairly satisfactorily (2.67) because 63 percent (5) has grades between 75-79. On the other hand, auditory learners performed very satisfactorily (3.21) because 57 percent (8) has 80-84 grades, and kinesthetic learners at 63 percent (5) performed satisfactorily (3.00) with grades between 80-84. The result implies that kinesthetics learners dominated this group of pupils whose academic achievement was very satisfactory and the rest was satisfactory and fairly satisfactory 
Table 4

The Difference between Learners' Demographic Profile and Learning Styles

\begin{tabular}{llllll}
\hline Learning Style vs & Statistical & Chi-square Value & P-value & Decision & Conclusion \\
\hline Sex & & $2.196^{\mathrm{a}}$ & 0.333 & Fail to Reject Ho & Not Significant \\
Ethnicity & Chi-square & $1.131^{\mathrm{a}}$ & 0.568 & Fail to Reject Ho & Not Significant \\
Hobby & $10.389^{\mathrm{a}}$ & 0.407 & Fail to Reject Ho & Not Significant \\
Access to Learning & & $9.643^{\mathrm{a}}$ & 0.141 & Fail to Reject Ho & Not Significant \\
\hline
\end{tabular}

*.05 level of Significance

Table 4 above reveals the difference between the learners' demographic profile and learning style at .05 level of significance. Using Chi-square, research showed that the demographic profile of learners such as sex $($ Chi-square $=2.196 \mathrm{a}$; $\mathrm{p}$-value $=0.333)$, ethnicity $($ Chi-square $=1,131 \mathrm{a} ; \mathrm{p}$-value $=0.568)$, hobby $($ Chi-square $=10.389 \mathrm{a} ; \mathrm{p}$-value $=$ $0.407)$, and access to learning (Chi-square $=9.643 \mathrm{a}$; $\mathrm{p}$-value $=0.141)$, has no significant difference in learning style. The result of the study, therefore, failed to reject the hypothesis that learners' demographic profile such as sex, ethnicity, access to learning, and hobby has no significant difference in learning styles.

The result on table 4 further implies that each one's learning style do es not rely either on our sex, ethnicity, access to learning, hobby, and therefore independent and is not influenced by demographic profile. This opposes the findings of Sarabi-Asiaba, et. al. (2014) that male students preferred to use the kinesthetic learning style more than females, while, female students preferred the aural learning style. The non-significant result of the study may be due to individual difference. Individual learning styles depend on cognitive, emotional, and environmental factors, as well as one's prior experience (Teach.com, 2008).

Table 5

The Relationship between Learners' Learning Styles and Academic Achievement

\begin{tabular}{cllll}
\hline Variable & Corr. Coef. & p-value & Decision & Interpretation \\
\hline *earning Style and Grades & 1.089 & .403 & Accept Ho & Not Significant \\
\hline 05 level of Significance & & & &
\end{tabular}

Table 5 reveals that learners' learning style and academic achievement has no significant relationship (Corr. Coef. $=.403, \mathrm{p}$-value $=.403$ ) at .05 level of significance after administering the Pearson-r correlations test. The result thereby failed to reject the hypothesis that learning styles and grades/academic achievement has no significant relationship. The result implies that academic achievement is not influenced nor driven by any specific learning style.

The findings obtained agreed with the findings of the study made by Awang, Abd, Samad, Faiz, Roddin, and Kankia (2017) that the learning style and academic achievement of students in Malaysian Polytechnic have no significant difference between learning style and academic achievement of students and are quite similar to their individual learning styles. These facts reveal that each learning style has its own strengths and weaknesses. However, the correlational study of Nzeseia (2015) among secondary school students in Kenya argues the result of the study. In his study, he 
found a strong positive and statistically significant relationship between learning styles and academic achievement for the trimodal learners, and among male and female students.

Table 6

Learners Preferred Learning Instruction

\begin{tabular}{ll}
\hline Learning Styles with Activities Applied & Percent of Effectiveness \\
\hline Visual Learners & 67 \\
Audio-Visual Presentation & 53 \\
Pictures on Meta-cards & 50 \\
Verbal Teaching only & 30 \\
Graphic Organizers & 26 \\
Plain Text Reading Materials & 25 \\
Realia/Real Objects & \\
Auditory Learners & 82 \\
Audio-Visual Presentation & 81 \\
Verbal Discussion/Teaching & 76 \\
Plain Text Reading Materials & 75 \\
Mnemonics & 67 \\
Picture analysis & 62 \\
Realia & 60 \\
Word Drills & 50 \\
Chorale Reading & 45 \\
Dictation & 72 \\
Kinesthetic Learners & 67 \\
Real Object/Realia & 62 \\
Verbal-finger Memorization & 50 \\
Simulation/ Drama & 50 \\
Chorale Reading & 47 \\
Demonstration by the teacher & 43 \\
Student-teacher interaction & 43 \\
Audio-visual presentation & 19 \\
Jotting down of notes & 14 \\
Games/Play & \\
No class interaction &
\end{tabular}

Table 6 shows the effectiveness of each activity/instruction applied by the teacher in four sessions to 30 pupils. The mean percentage scores were obtained as a result of the formative test that revealed visual learners learn best when the teacher used audio-visual presentation (67\%). As auditory learners, Audio-visual presentation $(82 \%)$ was their preferred learning instruction. Using real objects/tactile materials either by the teacher or them $(72 \%)$ after instruction/discussion is the preferred learning instruction of kinesthetic learners. 
The above result clearly implies that even learners in the mountainous community prefer an ICT (Information and Communication Technology) driven teaching instruction than that of the traditional ones. The numerical data obtained was further supported by the learners' responses during the interview . It can be elucidated that the learners in class are alive and are enjoying based on their responses.

Learners A and B both said that AVP enables them to clearly see the objects moving than just pictures that are flat.

"Ganahan ko sir nga ga gamit ug bidyo kay naga giho gyud." [Sir, I like it when you use video clip because it is moving.] -Learner A

"Klaro ka-ayo ang video sang sa picture." [The video is much clearer than that of the pictures.] -Learner B

Furthermore, learner $\mathrm{C}$ said that learning through AVP is not boring.

"Wala ko gapanguy-ab kay dili man ku tuyohon kay tagalog pod." [I do not yawn because it is not sleepy and because it is in Filipino language as well.]

While learner F said that "Lami kun ma kaptan gyud nimo kay ma tuyok mo gid, ug ma lingaw ka ba." [It is nice if it can be held by hand because I can manipulate it and its fun.]

\section{Summary of Findings}

In summary, the researcher found out that of the total population of grade five learners, of which male pupils dominated the population are multi-cultural, radio listeners, and passionate to draw. Moreover, it also shows that auditory learners having very satisfactory academic achievement dominated the classroom. Also, it reveals that these set of learners have their preferred learning styles, more specifically visual and auditory learners preferred learning with the aid of Audio-Visual Presentation, while kinesthetic learners learn best with the aid of real objects. Furthermore, the study shows no significant difference between demographic profile and learning style, and no significant relationship between learning style and academic achievement of the learners. It implies that learning styles are not dependent, not confined, and not influenced by a single demographic profile and academic achievement. Despite that learners were in a farflung school, having a limited exposure to technology, they already recognized its value in providing a meaningful learning experience.

\section{CONCLUSIONS}

The following conclusions were drawn out by the researcher from the findings of the data gathered. First, it can be concluded that learning styles are independent per se. It is not limited, influenced, or driven by any demographic profile understudy. Moreover, the academic achievement of the pupils was not influenced by nor influences any of the learning styles under study. Gaining knowledge is therefore not limited in a single instruction only. Thus, the researcher also concluded that among all the applied 
instruction to the three different types of learners, the use of both Audio-visual Presentation materials and real objects prevailed as the most preferred one. Despite they were in a remote area, where exposure to technology is rare, it is undeniable that the traditional ways of teaching are no longer desirable.

\section{RECOMMENDATIONS}

Here are the recommendations and suggestions made by the researcher based on the facts and findings.

Teachers have to consider that learning acquisition varies. So, giving instructions, activities, and learning materials to learners must be differentiated. This will allow the visual, auditory, and kinesthetic learners to explore the contents of the lessons from different methods and tasks offered. Such instructional materials should not only be on the content but also in the process, and output/product of the lessons. Teachers, as well, are suggested to update themselves about the proper use and integration of Audio-Visual Presentation, accompanied by a real/replica of objects or any tactile things during classroom teaching. The researcher also recommends the Department of Education to invest and produce more content-based educational videos (preferably in the Filipino language) and be available online.

\section{ACKNOWLEDGMENTS}

This paper was presented at the 19th CEBU- International Conference on Economics, Education, Humanities and Social Sciences (CEEHSS-19) on January 29-30, 2019 in Cebu City, Philippines. It was funded by the Department of Education (DepEd) under the Basic Education Research Fund (BERF). First, the author acknowledges Father Almighty as the source of his wisdom. He also acknowledges Central Philippines State University (CPSU) through its President, Dr. Aladino C. Moraca, Dr. Fernando D. Abello, Vice President for Academic Affairs, Dr. Joel A. Perez, VP for Research and Extension, Dr. Mae Flor G. Posadas, Director for Research and Development Services, and Engr. Marc Alexei Caesar B. Badajos, campus administrator of CPSU Sipalay for funding the presentation. To the Schools Division Office of Kabankalan City through the Schools Division Superintendent Ma. Lorlinie M. Ortillo, CESO VI, and the Division Research Committee Dr. Saturnino Pabalinas, Jr., secretariat, and SEPS for Research and Planning Rene S. Erillo for their guidance and help. Lastly, an acknowledgment to his parents Jocelyn and Maximiano, and brother Cedric James for the inspiration.

\section{REFERENCES}

Aranda, M. R., \& Zamora, J. (2016). Using differentiated instruction in improving the academic performance of students in the Filipino language. Retrieved from https://www.national-u.edu.ph/wp-content/uploads/2016/08/JSTAR-4_Aranda.pdf

Awang, H., Abd Samad, N., Faiz, N., Roddin, R. D., \& Kankia, J. (2017). Relationship between the learning styles preferences and academic achievement. IOP Conference 
Series: Materials Science and Engineering, 226, 012193. https://doi.org/10.1088/1757899X/226/1/012193.

Bryner, J. (2007). Most students bored at school. Retrieved from https://www.livescience.com/1308-students-bored-school.html

Dixon, F. A., Yssel, N., McConnell, J. M., \& Hardin, T. (2014). Differentiated instruction, professional development, and teacher efficacy. Journal for the Education of the Gifted, 37(2), 111-127. https://doi.org/10.1177/0162353214529042

Ferrier, M. A. (2007). The effects of differentiated instruction on academic achievement in a second-grade science classroom.

Flemming, N. (2001). Visual, auditory and kinesthetic (VAK) learning style model. Retrieved from https://martimurphy.com/pdf/VAK_Learning_Style_Model.pdf.

García, P., Amandi, A., Schiaffino, S., Campo, M. (2007). Evaluating Bayesian networks' precision for detecting students' learning styles. Comput Educ., 49(3), 794808. https://doi.org/10.1016/j.compedu.2005.11.017.

Hale, J. (2011). The 3 basic types of descriptive research methods. Psych Central. Retrieved from https://psychcentral.com/blog/the-3-basic-types-of-descriptive-researchmethods/

Hylton, K. (2017). Are learning styles important? Career \& Education. Retrieved April 22, 2019, from http://www.jamaicaobserver.com/career-education/are-learning-stylesimportant-_117401?profile $=1270$

Jaques, D., \& Salmon, G. (2006). Learning in groups: A handbook for face-to-face and online environments. Routledge

Kauffman, J. M., Mock, D. R., Tankersley, M., \& Landrum, T. J. (2008). Effective service delivery models. In R. J. Morris, \& N. Mather (Eds.), Evidence-based interventions for students with learning and behavioral challenges (pp. 359-378). Mahwah, NJ: Lawrence Erlbaum Associates.

Landrum, T., \& McDuffie, K. (2010) Learning Styles in the Age of Differentiated Instruction, Exceptionality, 18:1, 6-17, DOI: 10.1080/09362830903462441

Lawrence-Brown, D. (2004). Differentiated instruction: Inclusive strategies for standards-based learning that benefit the whole class. American Secondary Education $32(3), 34$.

Leonardo, R., Nivera, G., \& Reyes, A. (2015). Effects of differentiated learning on college students' achievement in and attitude towards trigonometry.

McQuarrie, L., McRae, P., \& Stack-Cutler, H. (2008). Differentiated instruction provincial research review. Edmonton: Alberta Initiative for School Improvement. 
Norman, G. (2009). When will learning style go out of style? Adv Health Sci Educ Theory Pract., 14(1),1-4.

Nzeseia, M.M. (2015). correlation study between learning styles and academic achievement among secondary school students in Kenya. Retrieved from http://erepository.uonbi.ac.ke/bitstream/handle/11295/93142/Mutua_A+correlation+stud $\mathrm{y}+$ between+learning+styles+and+academic+achievement+among+secondary+school.pd f? sequence $=1$

Othman, N., \& Amiruddin, M. H. (2010). Different perspectives of learning styles from VARK Model. Procedia Soc Behav Sci;7:652-60. doi: 10.1016/j.sbspro.2010.10.088.

Rock, M. L., Gregg, M., Ellis, E., \& Gable, R. A. (2008). REACG: A framework for differentiating classroom instruction. Preventing School Failure, 52(2), 31-47.

Sarabi-Asiabar, A., Jafari, M., Sadeghifar, J., Tofighi, S., Zaboli, R., Peyman, H., ... Shams, L. (2014). The relationship between learning style preferences and gender, educational major and status in first year medical students: a survey study from iran. Iranian Red Crescent medical journal, 17(1), e18250. doi:10.5812/ircmj.18250

Shenoy, N., \& Shenoy, K A. (2013). The perceptual preferences in learning among dental students in clinical subjects; 7(8):1683-5.

Singh, L. (2015). LEARNING STYLE PREFERENCES AMONG SECONDARY SCHOOL STUDENTS. 10.13140/RG.2.2.36377.72803.

Teach.com (2018). Learning Styles. All Students Are Created Equally (and Differently.) Retrieved April 21, 2019, from https://teach.com/what/teachers-know/learning-styles/

The Peak Performance Center (n.d.). Types of Learning Models. Retrieved April 24, 2019, from thepeakperformancecenter.com/educationallearning/learning/preferences/learning-styles//types-learning-style-models/

Tieso, C. (2005). The effects of grouping practices and curricular adjustments on achievement. Journal for the Education of the Gifted, 29(1), 60-89.

Tomlinson, C. A., \& Moon, T. (2014). Assessment in the Differentiated Classroom. Classroom Management and Assessment, 1-5.

Tomlinson, C. A., Brighton, C., Hertberg, H., Callahan, C. M., Moon, T. R., Brimijoin, K. Conover, L. A., \& Reynolds, T. (2003). Differentiating instruction in response to student readiness, interest, and learning profile in academically diverse classrooms: A review of literature. Journal of the Education of the Gifted, 27, 119-145.

Tomlinson, C. A. (1999). The differentiated classroom: Responding to the needs of all learners. Upper Saddle River, NJ: Pearson Education, Inc. 
VanBaren, J. (2019). What are the Types of Action Research Design? Retrieved April 22, 2019, from https://bizfluent.com/list-7608678-types-action-research-design.html

What's Your Learning Style (2009). Retrieved december 25, 2018, from http://people.usd.edu/ bwjames/tut/learning-style/ 